\title{
Unexplained diarrhoea in HIV-1 infected individuals
}

Bas B Oude Munnink ${ }^{1}$, Marta Canuti ${ }^{1}$, Martin Deijs ${ }^{1}$, Michel de Vries ${ }^{2}$, Maarten F Jebbink ${ }^{1}$, Sjoerd Rebers ${ }^{3}$, Richard Molenkamp ${ }^{3}$, Formijn J van Hemert ${ }^{1}$, Kevin Chung ${ }^{1}$, Matthew Cotten ${ }^{4}$, Fransje Snijders ${ }^{5}$, Cees JA Sol ${ }^{3^{\wedge}}$ and Lia van der Hoek ${ }^{1 *}$

\begin{abstract}
Background: Gastrointestinal symptoms, in particular diarrhoea, are common in non-treated HIV-1 infected individuals. Although various enteric pathogens have been implicated, the aetiology of diarrhoea remains unexplained in a large proportion of HIV-1 infected patients. Our aim is to identify the cause of diarrhoea for patients that remain negative in routine diagnostics.

Methods: In this study stool samples of 196 HIV-1 infected persons, including 29 persons with diarrhoea, were examined for enteropathogens and HIV-1. A search for unknown and unexpected viruses was performed using virus discovery cDNA-AFLP combined with Roche-454 sequencing (VIDISCA-454).

Results: HIV-1 RNA was detected in stool of 19 patients with diarrhoea (66\%) compared to 75 patients (45\%) without diarrhoea. In 19 of the 29 diarrhoea cases a known enteropathogen could be identified (66\%). Next to these known causative agents, a range of recently identified viruses was identified via VIDISCA-454: cosavirus, Aichi virus, human gyrovirus, and non-A non-B hepatitis virus. Moreover, a novel virus was detected which was named immunodeficiency-associated stool virus (IASvirus). However, PCR based screening for these viruses showed that none of these novel viruses was associated with diarrhoea. Notably, among the $34 \%$ enteropathogen-negative cases, HIV-1 RNA shedding in stool was more frequently observed (80\%) compared to enteropathogen-positive cases (47\%), indicating that HIV-1 itself is the most likely candidate to be involved in diarrhoea.
\end{abstract}

Conclusion: Unexplained diarrhoea in HIV-1 infected patients is probably not caused by recently described or previously unknown pathogens, but it is more likely that HIV-1 itself plays a role in intestinal mucosal abnormalities which leads to diarrhoea.

Keywords: Diarrhoea, HIV-1, VIDISCA-454, Aichi virus, Human gyrovirus, Cosavirus, Immunodeficiency-associated stool virus, NonA-nonB hepatitis virus, Norovirus, Sapovirus

\section{Background}

One of the most affected sites in untreated human immunodeficiency virus (HIV)-infected persons is the gastrointestinal tract [1-5]. In these patients diarrhoea occurs frequently, especially in HIV-1 patients who are not treated with anti-retroviral therapy. Routine diagnostics in fecal samples often remain negative, despite the sensitive diagnostic assays which are now available. In this study our

\footnotetext{
*Correspondence: c.m.vanderhoek@amc.uva.nl

Deceased

${ }^{1}$ Laboratory of Experimental Virology, Department of Medical Microbiology, Center for Infection and Immunity Amsterdam (CINIMA), Academic Medical Center of the University of Amsterdam, Amsterdam, The Netherlands

Full list of author information is available at the end of the article
}

aim is to identify the cause of diarrhoea for patients in which no enteropathogen could be found. There are several possible explanations why these patients remain negative in routine diagnostics: First, HIV-1 itself might play a role. HIV-1 infected mucosal cells have been observed in HIV-1 infected persons [6-11] and enterocytes exposed to HIV-1 show altered function and proliferation $[12,13]$. However, it has not been demonstrated that HIV-1 causes diarrhoea. Secondly, there are several recent reports describing novel viral agents which are found in stool that could play a role in diarrhoea (see below), and these agents are not yet included in routine diagnostics.

\section{Biomed Central}

(c) 2014 Oude Munnink et al.; licensee BioMed Central Ltd. This is an open access article distributed under the terms of the Creative Commons Attribution License (http://creativecommons.org/licenses/by/2.0), which permits unrestricted use, distribution, and reproduction in any medium, provided the original work is properly cited. 
Thirdly, an unknown or unexpected virus might be causing diarrhoea.

One of the recently described gastrointestinal viruses is cosavirus, which was identified in 2008 as a member of the Picornaviridae [14]. The virus was originally found in 2 patients with gastrointestinal infections $[14,15]$. However, its link with diarrhoea has not been established and a recent study in HIV-infected individuals detected cosavirus in a substantial number of patients without diarrhoea [16]. Aichi virus is another recently described picornavirus which was identified in fecal samples of patients with gastroenteritis [17]. Several manuscripts have since then confirmed that the virus is associated with diarrhoea [18,19], although in one study, which included children without diarrhoea, the association with disease could not be established since the amount of positive samples was too low [20]. Human gyrovirus, a member of the Circoviridae, is the most unusual novel virus which is found in gastrointestinal infections [21]. The virus is genetically very closely related to gyroviruses found in chicken meat [22] and therefore it remains uncertain whether human gyrovirus in stool is a sign of gastrointestinal infection or a virus which is digested with food and shed in feces, like many food related viruses [23].

Identification of unknown and unexpected viruses is performed via virus discovery cDNA-AFLP followed by Roche 454 sequencing (VIDISCA-454) [24]. This technique, which can detect single stranded and double stranded RNA and DNA viruses [25], has been developed in our laboratory and is a sensitive next generation sequencing-based assay which enables detection of known and unknown viruses in a wide range of different sample types, including stool samples [24,26-28].

In the current study, a cohort of 196 HIV-1 infected individuals of whom 29 suffered from severe diarrhoea was investigated. In this patient group we determined how many cases of diarrhoea could be explained by known enteropathogens, recently described viruses and unknown viruses.

\section{Methods}

\section{Patients}

One hundred and ninety-six HIV-1 infected patients, who visited the out-patient clinic at the Amsterdam Medical Center in 1994 and 1995, not on active antiretroviral therapy, were asked to bring a fresh stool sample at their next visit [29]. Criteria for inclusion in the study were proven HIV-1 infection and being aged 18 years or older.

Patients were asked to complete a questionnaire about the frequency and consistency of their stools during the week before the stool was collected. The definition of diarrhoea was loose or watery stool at least 3 times a day during the week prior to faeces collection (in accordance with the WHO guidelines for diarrhoea). In addition, patients were asked for the occurrence of additional symptoms and use of medication that might affect the consistency of stool. Hospital charts of patients were reviewed for additional clinical data and the local medical ethical committee of the AMC approved the study. Demographical data of our study population are shown in Table 1. Cultures were performed less than 4 hours after the specimen was collected (see below). Blood for serum storage and blood for CD4 cell count measurements were collected at the same date as stool collection. Stool samples were suspended in broth (1:3 dilution, Oxoid nutrient broth no.2, pH 7.5 and 500 IU penicillin per ml, $3 \mu \mathrm{g}$ amphotericin B per $\mathrm{ml}$ ). Serum and stool suspensions were stored at $-80^{\circ} \mathrm{C}$ until further use.

\section{CD4 cell counts}

$\mathrm{T}$ lymphocyte immunophenotyping for $\mathrm{CD} 4$ was carried out by flow cytofluorometry. PBMC were stained with CD4 mAb (Leu-3a-PE; Becton Dickinson, Mountain View, CA) according to the manufacturer's protocol.

\section{Virus diagnostics}

DNA was extracted from $110 \mu \mathrm{l}$ stool suspensions by the Boom extraction method [31]. Reverse transcription was performed as described [32]. Real time (RT-)PCRs specific

\section{Table 1 Demographic data of the study population}

\begin{tabular}{|c|c|c|c|}
\hline & $\begin{array}{l}\text { All } \\
(n=196)\end{array}$ & $\begin{array}{l}\text { Diarrhoea } \\
(n=29)\end{array}$ & $\begin{array}{l}\text { No diarrhoea } \\
(n=167)\end{array}$ \\
\hline Age, mean (SD) & $41(7)$ & $41(7)$ & $41(7)$ \\
\hline Male & $93 \%(183)$ & $97 \%(28)$ & $93 \%(155)$ \\
\hline Female & $7 \%(13)$ & $3 \%(1)$ & $7 \%(12)$ \\
\hline $\begin{array}{l}\text { CD4 count, } \\
\text { mean }(I Q R)^{1}\end{array}$ & $0.17(0.04-0.29)$ & $0.11(0.01-0.20)$ & $0.18(0.04-0.29)$ \\
\hline \multicolumn{4}{|l|}{ CDC stage ${ }^{2}$} \\
\hline 1 & $22 \%(43)$ & $9 \%(4)$ & $91 \%(39)$ \\
\hline 2 & $29 \%(56)$ & $13 \%(7)$ & $88 \%(49)$ \\
\hline 3 & $49 \%(97)$ & $19 \%(18)$ & $81 \%(79)$ \\
\hline \multicolumn{4}{|l|}{ Risk group } \\
\hline Homosexual & $85 \%(166)$ & $17 \%(28)$ & $83 \%(138)$ \\
\hline Heterosexual & $11 \%(21)$ & $5 \%(1)$ & $95 \%(20)$ \\
\hline Haemophiliac & $1 \%(2)$ & $0 \%(0)$ & $100 \%(2)$ \\
\hline Intravenous drug use & $4 \%(7)$ & $0 \%(0)$ & $100 \%(7)$ \\
\hline Blood transfusion & $1 \%(1)$ & $0 \%(0)$ & $100 \%(1)$ \\
\hline HIV-1 SI phenotype & $32 \%(62)$ & $21 \%(13)$ & $79 \%(49)$ \\
\hline P24 antigen in serum & $16 \%(32)$ & $3 \%(1)$ & $97 \%(31)$ \\
\hline $\begin{array}{l}\text { HIV-1 RNA load } \\
>4.9 \times 10^{4} \text { copies } / \mathrm{ml}\end{array}$ & $51 \%(99)$ & 19\% (19) & $81 \%(80)$ \\
\hline
\end{tabular}

${ }^{1} \mathrm{IQR}=$ inter quartile range.

${ }^{2}$ Stage 1: symptom free, 2: AIDS related symptoms that were not AIDS defining, 3: AIDS defining illness according to the CDC classification [30]. 
for rotavirus A and C, enterovirus, human parechovirus, norovirus genogroup I and II, astrovirus, sapovirus and adenovirus 40, 41 and 52 was performed (see Additional file 1: Table S1 for primer sequences) [32]. As internal control Equine Arteritis Virus (EAV) RNA was included. HIV-1 RNA detection in stool was determined as described [33]. Screening for viruses which were not in the diagnostic panel was done by PCR. Gyrovirus, Aichi virus, and non-A non-B hepatitis virus (NANBH virus) were diagnosed via nested PCR (see Additional file 1: Table S1 for primer sequences). All positive signals were confirmed by Sanger sequencing.

\section{Stool examination for intestinal parasites}

Intestinal parasites were detected in fresh stool by light microscopy: examination of direct smears and the Ridley concentration technique were both performed. Acid-fast staining was performed for detection of Cryptosporidia and Isospora species. Fluorescent staining with Uvitex 2B (Ciba-Geigy, Basel, Switzerland) was performed for detection of Microsporidia [34].

\section{Culture of enteropathogenic bacteria}

To isolate Salmonella and Shigella species, fresh stool specimens (within 4 hours after specimen collection) were plated on cystine lactose electrolyte-deficient medium (Brocalin agar; Merck, Darmstadt, Germany), SalmonellaShigella agar (Merck), Hektoen enteric agar (Difco, Detroit), Rappaport medium (Difco), MacConkey agar (Becton Dickinson, Cock-eysville, MD) and gram-negative broth (Hajna; Difco) as enrichment. A selective cefsulodin-irgasan-novobiocin medium (Oxoid, Basingstoke, Hampshire, England) and a glucose broth enrichment medium were used to isolate Yersinia species. Isolates were further characterized by using conventional bacteriologic methods, as outlined [35]. A cell-culture assay was used to detect Clostridium difficile toxin [36]. The Campylobacter-selective medium (modified Butzler medium) consisted of a solid 7\% hemolyzed sheep blood-based agar (nutrient broth no. 2) with cefoperazone $(30 \mathrm{mg} / \mathrm{L})$, rifampin $(10 \mathrm{mg} / \mathrm{L})$ and seroamphotericin B (2 mg/L) [29].

\section{VIDISCA and Roche Titanium-454 sequencing}

VIDISCA-454 was performed on $110 \mu \mathrm{l}$ stool suspension as previously described by De Vries et al. [25]. VIDISCAamplified nucleic acid - each with its own multiplex identifier (MID) - was quantified with the Quant-it dsDNA HS Qubit kit (Invitrogen) and diluted to $10^{6}$ copies $/ \mathrm{ml}$. All separate fractions were pooled and 4 pools from 14 different samples were used for a titration (DNA:beads ratio of $0.5: 1,1: 1,2: 1$ and 4:1) in an emulsion PCR according to the suppliers' protocol (LIB-A SV emPCR kit). Sequencing was done on a 4 region GS FLX Titanium PicoTiterPlate (70x75) with the GS FLX Titanium XLR 70 Sequencing kit (Roche).

\section{Sequence analysis}

Primer, MID and ribosomal RNA sequences were trimmed or removed from the reads. Sequences were assembled with CodonCode Aligner software version 3.5.6. The consensus sequences (contigs) and the unassembled reads were compared with the available sequences in Genbank [37] via the BlastN tool using default settings [38]. The blast output was used to create a taxonomic classification of the reads with Megan software version 4.70.4 [39]. The following settings were used: Min Support: 1, Min Score: 75, Min Score/Length: 0.75, Top Percent 100. Sequences without homology to known sequences were compared with less stringent settings to the available sequences in Genbank (expect threshold: 1000, Match/Mismatch Scores: 1.-1, Gap Costs: Existence: 2 Extension: 1), allowing more mismatches to occur in the comparison. Subsequently, the taxonomic classification of reads was also made with less stringent setting (Min Support: 1, Min Score: 10, Min Score/Length: 0.00, Top Percent 100). Additional file 1: Figure S1 represents a schematic overview of our analysis method.

\section{Statistical analysis}

Statistical analysis to determine the association with diarrhoea was performed with the Mid-P exact test, using the two by two table from OpenEpi [40]. Statistical analysis for the CD4 cell counts and the HIV-1 load was performed with the test of equality variance from OpenEpi [40].

\section{Accession numbers}

The complete genome sequence of NANBH-1 and NANBH-2 (uncultured phage WW-nAnB strain 2 and 3) and IAS virus have been deposited in GenBank under the accession numbers KJ003981 - KJ003983.

\section{Results}

\section{Known enteropathogens}

To investigate how many diarrhoea cases of HIV-1 infected individuals could be explained by infections with known pathogens, real time PCR, bacteria culture and microscopy was performed on stool samples of 196 HIV-1 infected patients of whom 29 had severe diarrhoea. The known diarrhoea agents parechovirus, astrovirus, rotavirus or adenovirus 40, 41 or 52 were not found in any of the 196 HIV-infected patients (see Table 2). Sapovirus was found in 3 patients with diarrhoea (10\%) and once in the control group (patients without diarrhoea), whereas norovirus was present in 10 patients with diarrhoea (34\%) compared to 13 controls $(7.8 \%)$. Statistical analysis showed that norovirus as well as sapovirus are associated with diarrhoea ( $\mathrm{p}$ value: 0.0006 and 0.02 respectively). Enterovirus was present in 3 patients with diarrhoea (10\%) and in 5 
Table 2 Prevalence of known enteropathogens

\begin{tabular}{llll}
\hline & $\begin{array}{l}\text { Diarrhoea } \\
\text { (n= 29) }\end{array}$ & $\begin{array}{l}\text { Non diarrhoea } \\
\text { (n= 167) }\end{array}$ & P-value* \\
\hline Norovirus & $34 \%(10)$ & $7.8 \%(13)$ & 0.0006 \\
Astrovirus & $0 \%(0)$ & $0 \%(0)$ & - \\
Adenovirus & $0 \%(0)$ & $0 \%(0)$ & - \\
Sapovirus & $10 \%(3)$ & $0.6 \%(1)$ & 0.02 \\
Enterovirus & $10 \%(3)$ & $3.0 \%(5)$ & 0.20 \\
Rotavirus & $0 \%(0)$ & $0 \%(0)$ & - \\
Parechovirus & $0 \%(0)$ & $0 \%(0)$ & - \\
HIV-1 in stool & $66 \%(19)$ & $45 \%(75)$ & 0.06 \\
Mycobacterium & $3.4 \%(1)$ & $0 \%(0)$ & 0.29 \\
Salmonella & $3.4 \%(1)$ & $0 \%(0)$ & 0.29 \\
Shigella & $0 \%(0)$ & $0 \%(0)$ & - \\
Yersinia & $0 \%(0)$ & $0 \%(0)$ & - \\
Clostridium diff & $0 \%(0)$ & $0.6 \%(1)$ & 0.99 \\
Campylobacter & $10 \%(3)$ & $3.0 \%(5)$ & 0.20 \\
Microsporidia & $6.9 \%(2)$ & $4.2 \%(7)$ & 0.79 \\
Giardia lamblia & $3.4 \%(1)$ & $0.6 \%(1)$ & 0.55 \\
Cryptosporidia & $10 \%(3)$ & $0.6 \%(1)$ & 0.02 \\
Pathogen negative & $34 \%(10)$ & $83 \%(139)$ & \\
\hline P-val & & \\
\hline
\end{tabular}

*P-values (Mid-P extract) in italics represent significant $p$-values for associating with diarrhoea.

patients in the control group (3.0\%), which is statistically not significantly different.

Five patients with diarrhoea (16.8\%) were infected with bacteria: Salmonella $\mathrm{n}=1$, Mycobacterium $\mathrm{n}=1$ and Campylobacter $\mathrm{n}=3$. On the other hand, bacteria were also observed in 6 patients (3.6\%) without diarrhoea (Clostridium difficile $\mathrm{n}=1$ and Campylobacter $\mathrm{n}=5$ ). Shigella and Yersinia were not detected in patients with or without diarrhoea. None of the bacterial infections were significantly associated with diarrhoea. Parasites were found in 6 patients (21\%) with diarrhoea (Cryptosporidia $\mathrm{n}=3$, Giardia lamblia $\mathrm{n}=1$ and Microsporidia $\mathrm{n}=2$ ), and in 9 patients (5.4\%) of the control group without diarrhoea (Cryptosporidia $\mathrm{n}=1$, Giardia lamblia $\mathrm{n}=1$ and Microsporidia $\mathrm{n}=7$ ). Of all parasitic infections, only Cryptosporidia was significantly associated with diarrhoea $(\mathrm{p}=0.02)$. We also screened for Cyclospora, Isospora, worm eggs and cysts but these pathogens were not significantly associated with diarrhoea in our study population (data not shown).

\section{VIDISCA-454}

After screening for known viruses, bacteria and parasites, 10 patients with diarrhoea (34\%) remained without diagnosis. We hypothesize that these patients are infected by an unknown or unexpected viral pathogen, and therefore a search for unknown or unexpected viruses was performed.
A total of 56 stool samples, including samples that remained negative in diagnostics, were selected and investigated by VIDISCA-454. Approximately 5,000 sequences per sample were compared with all sequences in the non-redundant database of Genbank, using the BLAST tool from NCBI (see Additional file 1: Figure S1). A total of 7,316 known viral sequences could be identified this way ( $2.7 \%$ of all sequences, see Table 3$)$.

Several viruses known to cause diarrhoea were found: sapovirus, enterovirus and norovirus (see Table 3). Furthermore, new candidate diarrhoea viruses were detected: human gyrovirus, cosavirus, and Aichi virus. In addition, known viruses of which it is not likely that they are involved in diarrhoea were detected: human adenovirus D viruses (type 23, 45 and 51, types which are not associated with diarrhoea), JC polyoma virus (probably originating from urine [41]), hepatitis B virus, rhinovirus (probably originating from respiratory tract) and human papilloma viruses. Furthermore torque teno viruses (TTV) and picobirnaviruses were found. TTVs represent an extremely diverse set of viruses which can differ substantially in their genome sequence and the size of their genome. These viruses have been detected in a large variety of clinical samples, and their association with any disease has not been established thus far [42]. Also picobirnaviruses are exceptionally diverse, they have been detected in diarrhoea patients, however, during outbreaks a diverse swarm of picobirnaviruses is observed making it less likely that these viruses cause diarrhoea [43].

Table 3 Quantification of the sequence reads from virus in stool samples of HIV-1 infected individuals

\begin{tabular}{ll}
\hline Virus: & Amount of sequences: \\
\hline Bacteriophages & 4269 \\
IAS virus & 2201 \\
Plant viruses & 1115 \\
Cryptosporidium parvum-virus & 813 \\
Torque teno virus & 662 \\
Norovirus & 215 \\
Sapovirus & 90 \\
Adenovirus D & 84 \\
Enterovirus & 37 \\
Cosavirus & 11 \\
NANBH-1 virus & 8 \\
JC polyomavirus & 4 \\
Human papillomavirus & 4 \\
Aichi virus & 3 \\
Hepatitis B virus & 3 \\
Picobirnavirus & 3 \\
Gyrovirus & 2 \\
Rhinovirus A & 1 \\
\hline
\end{tabular}


Interestingly, a high amount of sequences of Cryptosporidium parvum-virus was found in a patient infected with Cryptosporidium parvum. Detection of this virus in stool of a patient never has been reported, although it has been suggested to perform screening for the presence of this virus in environmental samples to determine if water is infected with the parasite [44].

Two variants of non-A non-B hepatitis virus (NANBH-1 and $\mathrm{NANBH}-2$ ) were found. The $\mathrm{NANBH}$ virus has been described in the 1980's in patients with non A non B hepatitis, at a time that hepatitis $C$ virus was not identified yet [45]. Since then no other study has investigated its presence in humans. NANBH viruses are circular dsDNA viruses and since the viruses were found by VIDISCA-454 in two patients with unexplained diarrhoea, their entire genome was sequenced. The viral genomes consist of 5,005 (NANBH-1) and 5,687 (NANBH-2) bps and both contain 4 open reading frames. The NANBH-2 virus is similar to the NANBH-1 except for a 687 nucleotide insertion in a non-coding region.

In addition, one novel virus was identified among the VIDISCA-454 reads, which we named immunodefiencyassociated stool virus (IAS virus). The virus was present in a high concentration in stool since large numbers of sequence reads belonged to the virus (2201 of 7316 sequences, see Table 3 and Additional file 1: Table S2). The complete genome sequence of IAS virus was determined. This novel virus carries a dsDNA genome of $99.980 \mathrm{bp}$. The virus is exceptional because it displays no significant similarity to any of the viruses known thus far. Real time PCR confirmed that the virus is present at a high load in the sample in which the virus was discovered $\left(1 \times 10^{7} \mathrm{DNA}\right.$ copies $\left./ \mathrm{ml}\right)$.

In addition to mammalian or vertebrate viruses, several bacteriophages and plant viruses were found. A total of 1,115 plant virus sequences $(0.4 \%)$ and 4,269 bacteriophage sequences (1.6\%) were identified (see Table 3 and Additional file 1: Table S2).

\section{Screening for novel and unexpected viruses}

Among the viruses which were detected via VIDISCA-454, there are several candidates that might be involved in the patients' diarrhoea. We focused on the most likely candidates to be involved in intestinal malfunctioning: human gyrovirus, cryptosporidium parvum-virus, Aichi virus and cosavirus, together with the new IAS virus and the unexpected NANBH virus. For these viruses a diagnostic PCR assay was developed (see Additional file 1: Table S1 for primer sequences). Of note, TTV and picobirnavirus, found by VIDISCA-454, were not included in the screening. Both virus families are extremely diverse and it is difficult, if not impossible, to develop proper diagnostic primers that can detect all variants. Furthermore, in literature TTVs have not been related to gastrointestinal disease.
All 196 patients - diarrhoea patients and subjects without diarrhoea - were tested for the abovementioned viruses. Cosavirus was found in 1 patient (3.4\%) with and in 2 patients (1.2\%) without diarrhoea (see Table 4). Human gyrovirus was detected in 33 individuals (17\%): in 29 controls (17\%) and 4 diarrhoea patients (14\%). Also Aichi virus was frequently found: 40 individuals (20\%) were positive of whom 34 had no diarrhoea (20\%) and 6 diarrhoea (21\%). IAS virus was detected in 2 patients with diarrhoea (6.9\%) and in 6 individuals without diarrhoea (3.6\%). The NANBH virus was detected in 2 patients with diarrhoea $(6.8 \%)$ and in 14 patients without diarrhoea $(8.4 \%)$. Thus, none of the novel or recently described viruses could be associated with diarrhoea.

Intriguingly, detection of the IAS virus was associated with low CD4 cell counts ( $\mathrm{p}<0.01$, two-tailed t-test), and exclusively occurred in patients with CDC-stage 2 or 3 . In contrast, detection of NANBH virus and human gyrovirus presence was not related to CD4 cell counts, and also occurred in the CDC-stage 1 patients (data not shown). However, Aichi virus detection was strongly related to CDC stage of the patient $(\mathrm{P}<0.0001)$ with most patients in $\mathrm{CDC}$ stage 2 or 3 being positive, however no relation with CD4 cell counts was observed.

Cryptosporidium parvum is a parasite which causes diarrhoea and screening for the virus which infects this parasite can potentially be used as an additional marker, next to the microscopic analysis for identification of the parasite. Microscope analysis showed that 3 patients with diarrhoea $(10 \%)$ and 1 patient without diarrhoea $(0.6 \%)$ were infected with Cryptosporidium parvum. The virus infecting the parasite was found in 2 patients with diarrhoea $(6.9 \%)$ and in 3 patients without diarrhoea (1.8\%) and was not associated with diarrhoea. Only one sample was found positive in both assays.

The role of HIV-1 itself in the unexplained diarrhoea was also examined. HIV-1 RNA was detectable in stool of 19 patients with diarrhoea (66\%) compared to 75 patients without diarrhoea (45\%). This association was not significant ( $p$ value: 0.06 ). It could be that HIV-1 shedding is just a sign of infection by pathogens, and that shedding of the virus occurs in case an enteropathogen disrupts the mucosal barrier. However, unexpectedly, in the group

Table 4 Prevalence of new viruses

\begin{tabular}{llll}
\hline & $\begin{array}{l}\text { Diarrhoea } \\
(\mathbf{n}=\mathbf{2 9})\end{array}$ & $\begin{array}{l}\text { Non diarrhoea } \\
(\mathbf{n}=\mathbf{1 6 7 )}\end{array}$ & P-value \\
\hline IAS virus & $6.9 \%(2)$ & $3.6 \%(6)$ & 0.67 \\
NANBH virus & $6.8 \%(2)$ & $8.4 \%(14)$ & 0.99 \\
Cosavirus & $3.4 \%(1)$ & $1.2 \%(2)$ & 0.77 \\
Cryptosporidium parvum-virus & $6.9 \%(2)$ & $1.8 \%(3)$ & 0.32 \\
Human gyrovirus & $14 \%(4)$ & $17 \%(29)$ & 0.87 \\
Aichi virus & $21 \%(6)$ & $20 \%(34)$ & 0.99 \\
\hline
\end{tabular}


without enteropathogens the frequency of HIV-1 RNA detection in stool was higher ( 8 out of $10,80 \%$ ) compared to the group where an enteropathogen could be found (9 out of 19,47\%), thus even an inverse relationship between HIV-1 shedding and infection by known pathogens was measured.

Finally, we could exclude that the use of antibiotics or other treatment was the cause of diarrhoea. In total 91 patients were treated with antibiotics, most of them with a combination of sulfamethoxazole and trimethoprim and there was no difference in antibiotic usage in diarrhoea cases compared to the control patients without diarrhoea (41\% versus $49 \%)$.

\section{Discussion}

Since the gastrointestinal tract is one of the most affected sites in untreated HIV-1 infections, the cause of diarrhoea in HIV-1 infected individuals was sought. After testing for all known enteropathogens, a pathogenic agent was detected in $66 \%$ of the diarrhoea cases. Virus infection accounted for $54 \%$ of the diarrhoea cases, bacterial infection was identified in $17 \%$, parasitic infection in $21 \%$ and also some dual infections were observed. Of all viruses, norovirus accounts for the majority of infections (34\%), followed by sapovirus and enterovirus (10\% each). Still, in 34\% of the patients with diarrhoea the causative agent could not be found. A careful investigation of the cause of unexplained diarrhoea in these 10 patients was performed using deep sequencing strategies. We were able to identify several recently described and one new virus with VIDISCA-454 (e.g. NANBH virus, cosavirus, Aichi virus, human gyrovirus and a novel IAS virus). However, no association between these viruses and diarrhoea was observed.

Remarkably, the prevalence of Aichi virus in our study population was $20 \%$, while previous studies only showed a prevalence of $0.5-1.6 \%[19,46]$. It could be that the virus is more frequently present in patients with immunodeficiency. Furthermore, the sensitivity of our assay may also play a part. In our study a very sensitive nested PCR assay was used which enables detection of the virus even if it is present at low concentrations. To exclude that the high prevalence was caused by PCR contamination, all positive PCR products were sequenced. Variation between the viruses from different patients was observed, thereby excluding contamination by a single source (see nucleotide alignments in Additional file 1: Table S3).

Human gyrovirus was detected in 33 patients. This study is the first study that shows that this virus was already present in the Netherlands in 1994 and 1995. The virus was present in $17 \%$ of the individuals without diarrhoea, compared to $14 \%$ of the patients, indicating that it is unlikely that the virus is involved in disease. Since antibody response against this virus has not been described thus far, combined with the fact that this virus was also found in chicken [22], we hypothesize that detection of human gyrovirus in stool may very well be food related.

Cryptosporidium parvum-virus PCR screening resulted in 5 positive samples, but it also showed that detection of the virus is not associated with diarrhoea. Screening for cryptosporidium parvum-virus has already been suggested as an alternative test to detect the parasite in surface water [44]. However, since microscopic analysis for the parasite itself did show a diarrhoea-association, we propose that only screening for the Cryptosporidium parvum, and not the virus infecting the parasite, should be performed in diagnostics of patients.

The NANBH virus was present in some of our study subjects in high viral loads. Recently, an Inovirus (a bacteria infecting virus family) was described by Cantalupo et al. [47] that resembles the NANBH virus (90\% identity). This resemblance strongly indicates that the NANBH-1 and the NANBH-2 viruses are bacteriophages and in this respect it is not surprising that no correlation with diarrhoea was found here.

Finally, the role of HIV-1 self was investigated. Remarkably, although not significant, HIV-1 RNA was detected more in stool samples in patients where no enteropathogen could be found compared to the group with enteropathogen. This result indicates that shedding of HIV-1 in feces is not the direct result of damage to the mucosal barrier by enteropathogens, but that HIV-1 itself may damage the mucosal barrier and cause diarrhoea. Detection of HIV-1 in stool was not related to the stage of HIV-1 disease since CD4 cell count, CDC stage, and HIV-1 viral load did not differ significantly between diarrhoea patients with enteropathogen and people without enteropathogen (data not shown). The relatively low number of patients with unexplained diarrhoea is a limitation of our study. In the future, a study focusing on unexplained diarrhoea should include more HIV-1 positive patients with unexplained diarrhoea to be able to confirm our hypothesis that HIV-1 itself plays a role in gastrointestinal disorders.

\section{Conclusions}

Virus discovery has in recent years revealed several previously unknown viruses for which it has been postulated that they are involved in diarrhoea. In the study presented here we show that infection by these novel agents does not explain the high frequency of diarrhoea in HIV-1 infected patients. Also the novel IAS virus could not be linked to diarrhoea, but interestingly, it was associated with advanced stages of HIV-1 disease. Further investigation of this virus may reveal whether the virus is a human virus or a virus infecting bacteria. Sequence comparison could not clarify this, since the virus has no sequence identity to any of the viruses known thus far.

In the early HIV-1 literature it has been shown that HIV-1 has an effect on enterocytes. This knowledge 
combined with our detection of HIV-1 in stool - especially in those patients which remained negative in diagnostics - suggests that HIV-1 may cause the gastrointestinal damage and the resulting diarrhoea. Further research with cell culture based techniques is needed to reveal the role of HIV-1 in gastrointestinal disease.

\section{Additional file}

Additional file 1: Table S1. Primer combination used for the screening. Table S2: Quantification of the detection of viral families in stool samples of HIV-1 infected individuals. Table S3: Alignment of the sequences of the different aichi viruses. Figure S1: Pipeline of the data analysis.

\section{Competing interests}

The authors declare that they have no competing interests.

\section{Authors' contributions}

BBOM carried out the virus discovery studies and drafted the manuscript. MCa, MD, and MdV carried out the VIDISCA-454 runs, MFJ carried out sequence analysis, SR and RM performed the viral diagnostics, FJvH carried out protein structure analysis, MCo and KC participated in full length sequencing of unknown viruses, FS was involved in design of the study and patient inclusion, CJAS initiated the study, LvdH supervised the study, participated in its design, and helped to draft the manuscript. All authors except CJAS have read and approved the final manuscript.

\section{Acknowledgements}

We are indebted to our deceased friend and colleague Cees J.A. So (Academic medical Center, Amsterdam, the Netherlands) for valuable discussions and the initiation of this study. This study was supported by funding from the European Community's Seventh Framework Programme (FP7/2007-2013) under the project EMPERIE, EC grant agreement number 223498, and VIDI grant 016.066.318 from the Netherlands Organization for Scientific Research (NWO).

\section{Author details}

'Laboratory of Experimental Virology, Department of Medical Microbiology, Center for Infection and Immunity Amsterdam (CINIMA), Academic Medical Center of the University of Amsterdam, Amsterdam, The Netherlands. ${ }^{2}$ CBS-KNAW Fungal Biodiversity Center, Utrecht, The Netherlands. ${ }^{3}$ Laboratory of Clinical Virology, Department of Medical Microbiology, Center for Infection and Immunity Amsterdam (CINIMA), Academic Medical Center of the University of Amsterdam, Amsterdam, The Netherlands. ${ }^{4}$ Wellcome Trust Sanger Institute, Hinxton, CB10 1SA, UK. ${ }^{5}$ Beatrix Hospital, Gorinchem, The Netherlands.

Received: 17 May 2013 Accepted: 8 January 2014

Published: 13 January 2014

\section{Reference}

1. Dworkin B, Wormser GP, Rosenthal WS, Heier SK, Braunstein M, Weiss L, Jankowski R, Levy D, Weiselberg S: Gastrointestinal manifestations of the acquired immunodeficiency syndrome: a review of 22 cases. Am $J$ Gastroenterol 1985, 80:774-778

2. Gazzard BG: Diarrhea in human immunodeficiency virus antibody-positive patients. Semin Liver Dis 1992, 12:154-166.

3. Gillin JS, Shike M, Alcock N, Urmacher C, Krown S, Kurtz RC, Lightdale CJ, Winawer SJ: Malabsorption and mucosal abnormalities of the small intestine in the acquired immunodeficiency syndrome. Ann Intern Med 1985, 102:619-622

4. Griffin GE: Human immunodeficiency virus and the gastrointestinal tract. Baillieres Clin Gastroenterol 1990, 4:119-134.

5. Kotler DP, Gaetz HP, Lange M, Klein EB, Holt PR: Enteropathy associated with the acquired immunodeficiency syndrome. Ann Intern Med 1984, 101:421-428.
6. Fox $\mathrm{CH}$, Kotler D, Tierney A, Wilson CS, Fauci AS: Detection of HIV-1 RNA in the lamina propria of patients with AIDS and gastrointestinal disease. $J$ Infect Dis 1989, 159:467-471.

7. Heise C, Dandekar S, Kumar P, Duplantier R, Donovan RM, Halsted CH: Human immunodeficiency virus infection of enterocytes and mononuclear cells in human jejunal mucosa. Gastroenterology 1991, 100:1521-1527.

8. Jarry A, Cortez A, Rene E, Muzeau F, Brousse N: Infected cells and immune cells in the gastrointestinal tract of AIDS patients. An immunohistochemical study of 127 cases. Histopathology 1990, 16:133-140.

9. Kotler DP, Reka S, Borcich A, Cronin WJ: Detection, localization, and quantitation of HIV-associated antigens in intestinal biopsies from patients with HIV. Am J Pathol 1991, 139:823-830.

10. Nelson JA, Wiley CA, Reynolds-Kohler C, Reese CE, Margaretten W, Levy JA Human immunodeficiency virus detected in bowel epithelium from patients with gastrointestinal symptoms. Lancet 1988, 1:259-262.

11. Ullrich R, Zeitz M, Heise W, L'age M, Hoffken G, Riecken EO: Small intestinal structure and function in patients infected with human immunodeficiency virus (HIV): evidence for HIV-induced enteropathy. Ann Intern Med 1989, 111:15-21.

12. Asmuth DM, Hammer SM, Wanke CA: Physiological effects of HIV infection on human intestinal epithelial cells: an in vitro model for HIV enteropathy. AIDS 1994, 8:205-211.

13. Batman PA, Fleming SC, Sedgwick PM, MacDonald TT, Griffin GE: HIV infection of human fetal intestinal explant cultures induces epithelial cell proliferation. AIDS 1994, 8:161-167.

14. Kapoor A, Victoria J, Simmonds P, Slikas E, Chieochansin T, Naeem A, Shaukat S, Sharif S, Alam MM, Angez M, et al: A highly prevalent and genetically diversified Picornaviridae genus in South Asian children. Proc Natl Acad Sci U S A 2008, 105:20482-20487.

15. Holtz $L R$, Finkbeiner $S R$, Kirkwood CD, Wang D: Identification of a novel picornavirus related to cosaviruses in a child with acute diarrhea. Virol $J$ 2008, 5:159.

16. Stocker A, Souza BF, Ribeiro TC, Netto EM, Araujo LO, Correa Jl, Almeida PS, de Mattos AP, Ribeiro HC Jr, Pedral-Sampaio DB, et al: Cosavirus infection in persons with and without gastroenteritis, Brazil. Emerg Infect Dis 2012, 18:656-659.

17. Yamashita T, Kobayashi S, Sakae K, Nakata S, Chiba S, Ishihara Y, Isomura S: Isolation of cytopathic small round viruses with BS-C-1 cells from patients with gastroenteritis. J Infect Dis 1991, 164:954-957.

18. Yang S, Zhang W, Shen Q, Yang Z, Zhu J, Cui L, Hua X: Aichi virus strains in children with gastroenteritis, China. Emerg Infect Dis 2009, 15:1703-1705.

19. Ambert-Balay K, Lorrot M, Bon F, Giraudon H, Kaplon J, Wolfer M, Lebon P, Gendrel D, Pothier P: Prevalence and genetic diversity of Aichi virus strains in stool samples from community and hospitalized patients. J Clin Microbiol 2008, 46:1252-1258

20. Nielsen AC, Gyhrs ML, Nielsen LP, Pedersen C, Bottiger B: Gastroenteritis and the novel picornaviruses aichi virus, cosavirus, saffold virus, and salivirus in young children. J Clin Virol 2013, 57:239-242.

21. Gia PT, Phung VN, Sdiri-Loulizi K, Aouni M, Pothier P, Ambert-Balay K, Deng $X$, Delwart $E$ : Divergent gyroviruses in the feces of Tunisian children. Virology 2013, 446:346-348.

22. Chu DK, Poon LL, Chiu SS, Chan KH, Ng EM, Bauer I, Cheung TK, Ng IH, Guan Y, Wang D, et al: Characterization of a novel gyrovirus in human stool and chicken meat. J Clin Virol 2012, 55:209-213.

23. Oude Munnink BB, Jazaeri Farsani SM, Deijs M, Jonkers J, Verhoeven JT, leven M, Goossens H, de Jong MD, Berkhout B, Loens K, et al: Autologous antibody capture to enrich immunogenic viruses for viral discovery. PLOS One 2013, 8:e78454.

24. van der Hoek L, Pyrc K, Jebbink MF, Vermeulen-Oost W, Berkhout RJ, Wolthers KC, Wertheim-van Dillen PM, Kaandorp J, Spaargaren J, Berkhout B: Identification of a new human coronavirus. Nat Med 2004, 10:368-373.

25. de Vries $M$, Deijs $M$, Canuti M, van Schaik BD, Faria NR, van de Garde MD, Jachimowski LC, Jebbink MF, Jakobs M, Luyf AC, et al: A sensitive assay for virus discovery in respiratory clinical samples. PLoS One 2011, 6:e16118.

26. de Vries M, Pyrc K, Berkhout R, Vermeulen-Oost W, Dijkman R, Jebbink MF, Bruisten S, Berkhout B, van der Hoek L: Human parechovirus type 1, 3, 4, 5, and 6 detection in picornavirus cultures. J Clin Microbiol 2008, 46:759-762.

27. Canuti M, Eis-Huebinger AM, Deijs M, de Vries M, Drexler JF, Oppong SK, Müller MA, Klose SM, Wellinghausen N, Cottontail VM: Two novel parvoviruses in frugivorous new and old world bats. PLoS One 2011, 6:e29140. 
28. van der Heijden $M$, de Vries M, van Steenbeek FG, Favier RP, Deijs M, Brinkhof B, Rothuizen J, van der Hoek L, Penning LC: Sequence-independent VIDISCA-454 technique to discover new viruses in canine livers. J Virol Methods 2012, 185:152-155.

29. Snijders F, Kuijper EJ, de Wever B, van der Hoek L, Danner SA, Dankert J, de WB: Prevalence of Campylobacter-associated diarrhea among patients infected with human immunodeficiency virus. Clin Infect Dis 1997, 24:1107-1113.

30. Castro KG, Ward JG, Slutsker L, Buehler JW, Jaffe HW, Berkelman RL, Curran JW: 1993 revised classification system for HIV infection and expanded surveillance case definition for AIDS among adolescents and adults. MMWR Recomm Rep 1992, 41:1-19.

31. Boom R, Sol CJ, Salimans MM, Jansen CL, Wertheim-van Dillen PM, van der Noordaa J: Rapid and simple method for purification of nucleic acids. J Clin Microbiol 1990, 28:495-503.

32. Jansen RR, Schinkel J, Koekkoek S, Pajkrt D, Beld M, de Jong MD, Molenkamp R: Development and evaluation of a four-tube real time multiplex PCR assay covering fourteen respiratory viruses, and comparison to its corresponding single target counterparts. J Clin Virol 2011, 51:179-185.

33. van der Hoek L, Boom R, Goudsmit J, Snijders F, Sol CJ: Isolation of human immunodeficiency virus type 1 (HIV-1) RNA from feces by a simple method and difference between HIV-1 subpopulations in feces and serum. J Clin Microbiol 1995, 33:581-588.

34. van Gool T, Snijders F, Reiss P, Eeftinck Schattenkerk JK, van den Bergh Weerman MA, Bartelsman JF, Bruins JJ, Canning EU, Dankert J: Diagnosis of intestinal and disseminated microsporidial infections in patients with HIV by a new rapid fluorescence technique. J Clin Pathol 1993, 46:694-699.

35. Grasmick A: Processing and interpretation of bacterial fecal cultures. In Clinical Microbiology Procedures Handbook, vol. 1. Edited by Isenberg HD. Washington, D.C: American Society for Microbiology; 1992:1.10.1-1.10.25.

36. Maniar AC, Williams TW, Hammond GW: Detection of Clostridium difficile toxin in various tissue culture monolayers. J Clin Microbiol 1987, 25:1999-2000

37. Benson DA, Karsch-Mizrachi I, Lipman DJ, Ostell J, Sayers EW: GenBank. Nucleic Acids Res 2010, 38:D46-D51.

38. Altschul SF, Gish W, Miller W, Myers EW, Lipman DJ: Basic local alignment search tool. J Mol Biol 1990, 215:403-410.

39. Huson DH, Mitra S, Ruscheweyh HJ, Weber N, Schuster SC: Integrative analysis of environmental sequences using MEGAN4. Genome Res 2011, 21:1552-1560.

40. Sullivan KM, Dean A, Soe MM: OpenEpi: a web-based epidemiologic and statistical calculator for public health. Public Health Rep 2009, 124:471-474.

41. Van Loy T, Thys K, Tritsmans L, Stuyver LJ: Quasispecies analysis of JC virus DNA present in urine of healthy subjects. PLoS One 2013, 8:e70950.

42. Okamoto H: History of discoveries and pathogenicity of $\Pi \mathrm{T}$ viruses. Curr Top Microbiol Immunol 2009, 331:1-20.

43. Banyai K, Jakab F, Reuter G, Bene J, Uj M, Melegh B, Szucs G: Sequence heterogeneity among human picobirnaviruses detected in a gastroenteritis outbreak. Arch Virol 2003, 148:2281-2291.

44. Kniel KE, Higgins JA, Trout JM, Fayer R, Jenkins MC: Characterization and potential use of a Cryptosporidium parvum virus (CPV) antigen for detecting C. parvum oocysts. J Microbiol Methods 2004, 58:189-195.

45. Seelig R, Liehr H, Seelig HP: Detection of a non-A, non-B hepatitis associated substance in stools. Dev Biol Stand 1983, 54:497-500.

46. Kaikkonen S, Rasanen S, Ramet M, Vesikari T: Aichi virus infection in children with acute gastroenteritis in Finland. Epidemiol Infect 2010, 138:1166-1171.

47. Cantalupo PG, Calgua B, Zhao G, Hundesa A, Wier AD, Katz JP, Grabe M, Hendrix RW, Girones R, Wang D, et al: Raw sewage harbors diverse viral populations. MBio 2011, 2(5). doi: 10.1128/mBio.00180-11.

doi:10.1186/1471-2334-14-22

Cite this article as: Oude Munnink et al:: Unexplained diarrhoea in HIV-1 infected individuals. BMC Infectious Diseases 2014 14:22.

\section{Submit your next manuscript to BioMed Central and take full advantage of:}

- Convenient online submission

- Thorough peer review

- No space constraints or color figure charges

- Immediate publication on acceptance

- Inclusion in PubMed, CAS, Scopus and Google Scholar

- Research which is freely available for redistribution

Submit your manuscript at www.biomedcentral.com/submit 